\title{
Does IFRS Drive Information Asymmetry Reduction? Evidence from Asean-6 Countries
}

\author{
MARYAM YOUSEFI NEJAD, AZLINA AHMAD, RUZITA ABDUL RAHIM \& FAIRUZ MD \\ SALLEH
}

\section{ABSTRACT}

International Financial Reporting Standard (IFRS) is globally accepted as a high-quality reporting standard. Countries implement IFRS because they believe that more disclosure leads to agency costs reduction and may result in adverse selection costs or information asymmetry reduction. However, studies on the relationship between IFRS and information asymmetry have thus far provided mixed evidence. On the other side, there are limited studies in this area that are focused on ASEAN countries. Therefore, more studies are needed to better understand whether IFRS drives information asymmetry reduction especially in ASEAN countries as developing countries. Therefore, this study contributes to knowledge by examining the association between IFRS and information asymmetry within ASEAN-6 countries, as a setting for developing countries. The results of the OLS (Static Panel estimation technique) indicate that IFRS has a negative and significant relationship with information asymmetry. It reveals that IFRS results in information asymmetry reduction throughout ASEAN-6 countries. Besides using the OLS, this study also applies a Generalized Moment Method (GMM) as an additional test, to measure dynamic relationships and correct the potential endogeneity problem between IFRS and information asymmetry. Besides theoretical and methodological contributions, findings of this study are useful for the adopter and non-adopter countries to understand the consequences of IFRS compliance on information asymmetry. The findings provide important inputs to policymakers of Indonesia and Vietnam who are contemplating adopting IFRS.

Keywords: IFRS; Information Asymmetry; ASEAN; Developing Countries; Bid-Ask Spread; Illiquidity; Information Quality; GMM

\section{INTRODUCTION}

This study investigates the relationship between International Financial Reporting Standards (IFRS) and information asymmetry reduction in ASEAN-6 countries, using Bid-Ask Spread and Illiquidity as information asymmetry measurements derived from the microstructure literature. A critical challenge for all countries is to attract more investors to invest in their companies. However, in the capital market, the relationship between companies and investors is complicated due to two reasons (Healy \& Palepu 2001). First, companies normally have more and better information about companies' value than investors, as well as they have the incentive to overstate their value. In other words, normally there is information asymmetry between companies and investors due to uncertainty in companies' value (Nagar, Schoenfeld \& Wellman 2018). Second, investors and companies, are self-interested agents that alter the uncertainty of companies' value for their own benefit and lead to the agency problem. In the uncertainty of companies' value, some investors collect private information about companies' value before investment, therefore, they create information asymmetry and illiquidity or make wider differences between bid and ask (Amihud 2002; Nagar et al. 2018). Indeed, investors are likely to choose companies to investment which disclosed high-quality information to minimize their information costs (processing costs and adverse selection cost) (He 2002; Azubuike 2006; Blankespoor 2012).

Additionally, previous studies argued that the decision about investment' location, are made under the conditions of uncertainties (Anderson \& Gatignon 1986; Ulgado 1997). The uncertainties may occur due to inadequacy of information (Miller 1992). Due to the inadequacy of information, investors have to bear the cost of acquiring, absorbing, processing information and making decisions and plans based on inadequacy information, therefore, the information costs will increase (Verona 2014). Indeed, information asymmetry leads to higher information costs for investors and as information costs affect investors' behaviour (He 2002; Ahearne, Griever \& Warnock 2004; Verona 2014), it can be concluded that information asymmetry may affect investment decisions (Yousefinejad, Ahmad \& Rahim 2018). 
One way to reduce information asymmetry is to have in place a globally accepted high-quality reporting standards such as IFRS. The adoption of IFRS around the world has been one of the most important regulatory changes in financial reporting in many years. The purpose of this regulatory change is to improve the comparability and transparency of accounting information. IFRS has been associated with improved accounting information quality which may lead to information asymmetry reduction and ultimately information costs reduction primarily for investors who are familiar with IFRS (Ramamurti 2012; Choi, Rhee \& Oh 2014; Rehman \& Shahzad 2014; Lourenço \& Branco 2015; Aliabadi \& Shahri 2016; Silva Junior, Caldeira \& Silva Torrent 2017; Vinh Vo 2018) and may also facilitate cross-border capital flows (Akisik 2008; Gordon et al. 2012; Naranjo et al. 2013; Nejad et al. 2018). Therefore, based on the above discussion, it can be proposed that IFRS has the potential to reduce the level of information asymmetry.

Typically, investors are attracted to locations that have higher financial information quality. As discussed before, this is because high-quality financial reporting is a reflection of corporate transparency and comparability (Chipalkatti, Le \& Rishi 2007; Owusu et al. 2017). Therefore, many countries choose to implement IFRS in order to increase transparency, comparability and eventually reduce level of information asymmetry (Chen, Ding \& Xu 2014; Cho, Kwon, Yi \& Yun 2015; Turki, Wali \& Boujelbene 2017; Nejad, Ahmad, Salleh \& Rahim, 2018). However, thus far, extant empirical studies have reported mixed evidence as to whether IFRS leads to reduce information asymmetry.

Among past studies that reported positive consequences of IFRS with regard to information asymmetry improvement are Armstrong et al. (2008) and Abad et al. (2017) in European countries, Cormier (2014) in Canada and Kao and Wei (2014) in China. However, there are some studies that have concluded IFRS adoption does not necessarily reduce information asymmetry. The studies include Jeanjean and Stolowy (2008) and Sellami (2016) in Australia, France and the UK, Ahmed, Neel and Wang (2013) in 20 countries and Timm, Fátima, Costa and Zóboli (2016) in Latin American. The mixed evidences provide an opportunity to shed further light on the debate surrounding the effects of IFRS on information asymmetry and examine whether IFRS can benefit developing countries. Therefore, this study examines the IFRS effects on information asymmetry in ASEAN-6 countries consist of Indonesia, Malaysia, Philippines, Singapore, Thailand, and Vietnam.

Previous studies have reported investors prefer markets with high-quality accounting information and less information asymmetry that enable them to assess investment opportunities at lower information costs (He 2002; Ahearne et al. 2004; Bellalah et al. 2016; Yousefinejad, Ahmad \& Rahim 2018). As IFRS is considered as a highquality reporting standard, therefore, implementation of IFRS is expected to improve financial information quality, resulting in information asymmetry reduction (Ramamurti 2012; Choi, Rhee \& Oh 2014; Rehman \& Shahzad 2014; Lourenço \& Branco 2015; Aliabadi \& Shahri 2016; Silva Junior, Caldeira \& Silva Torrent 2017; Vinh Vo 2018; Nejad et al. 2018). As mentioned before, this study concentrates on ASEAN-6 countries, however, within ASEAN, two countries which are Indonesia and Vietnam have not adopted IFRS (IASB 2016) ${ }^{1}$. Previous theoretical and empirical results on whether IFRS improves information asymmetry, have reported inconclusive findings that open room for further studies on this area. Therefore, this study contributes to the extant literature by investigating the effect of IFRS on information asymmetry in ASEAN-6 countries.

Although, there are studies (Naranjo, Saavedra \& Verdi 2013; Cho et al. 2015; Turki, Wali \& Boujelbene 2017; Abad et al. 2017) that addressed issues that are similar to those considered in this study, however, this study differs substantially from others in the following ways. Firstly, in the best of knowledge, there are limited studies that are considered the ASEAN region as the sample of the study. Second, this study applies two different measurements for IFRS adoption, Dummy variables, and level of compliance with IFRS. As mentioned before, Vietnam and Indonesia have not adopted IFRS yet, however, Indonesia, unlike Vietnam, has a public commitment towards IFRS as a single set of high-quality global accounting standards. Using this measurement for IFRS provides an opportunity to examine the effect level of compliance with IFRS on information asymmetry. Third, in order to minimize estimation biases for the testing of the hypothesis, this study employs several estimation techniques which are OLS and GMM. In the best of knowledge, there is no study that has applied GMM to examine the relationship between IFRS adoption and information asymmetry.

The outcomes of this study would provide important inputs to policymakers of not only countries that have already adopted IFRS but also to policymakers in countries that have not adopted IFRS, especially Indonesia and Vietnam. If the results of this study also confirmed the positive effect of IFRS implementation on information asymmetry, findings of this study will encourage policymakers of other developing countries to pay more attention to their infrastructures, such as fiscal and taxation policies, to ensure a smooth transition. Additionally, feedback on the effectiveness of policy implementation can help policymakers plan to way forward and actions to take for improvements. For countries that are contemplating to IFRS adoption, information on the effectiveness of policy implementation of other countries can help them plan the best way to proceed and what to expect based on the experiences of others before them. 
This study is organized as follows. The next section provides a brief review of the relevant literature. This is followed by discussion of hypothesis development, research design and sample, research models and findings. The final section presents the limitation of the study and suggestions for future research.

\section{LITERATURE REVIEW}

IFRS has been implemented by countries to improve reporting quality, reduce information processing costs, and reduce information asymmetry among capital market participants within and across countries. (Gordon et al. 2012; Aliabadi \& Shahri 2016; Persakisa \& Iatridis 2017; Abad et al. 2017). The reduction in information asymmetry would occur with IFRS implementation for two potential reasons. First, IFRS significantly increases accounting disclosure by providing additional disclosure guidelines. Second, IFRS significantly increases comparability and transparency which help investors to make better decisions (Zhai \& Wang 2016).

Information asymmetry occurs when in a transaction, one party (company) has more or better information than the other (investor) or investors face with incomplete and imperfect information. Therefore, investors will face investment risk. Empirical evidence is consistent with the idea that higher financial information quality, that is achievable by IFRS, leads to increase investor confidence through the information asymmetry reduction (Abad et al. 2017). Previous studies found that higher transparency in financial reporting and disclosure lead to reduce information asymmetry. According to Glosten and Milgron (1985), lower levels of information asymmetry leads to more informed valuation, reducing adverse selection cost and leads to increase market liquidity. IFRS is recognized to be a set of principles-based financial reporting standards that allow companies to prepare and disclose information that better reflect their financial and economic reality. IFRS are more rigorous about accounting alternatives and measurement requirements, which reduces the management opportunistic discretion in determining accounting amounts. Therefore, reducing opportunistic behavior leads to reduce the manipulations and increases the quality of financial information (Ball, Robin \& Wu 2003). Consequently, if IFRS increases financial information quality, the information asymmetry after IFRS adoption might be improved.

Among studies that show the positive effect of IFRS on information asymmetry is Leuz and Verrecchia (2000) that showed IFRS results in better transparency of financial reporting and reduce information asymmetry, uncertainties and estimation risks. As well as Leuz and Verrecchia (2000) found IFRS can lead to lower cost of capital and enhance market liquidity. Armstrong et al. (2008) found information asymmetry reduced after IFRS adoption in the EU countries. Similar to Armstrong et al. (2008), Preiato, Brown and Tarca (2009) examined the effect of mandatory IFRS adoption on information asymmetry in the EU and Australia from 2002 to2007. The study found a significant reduction in information asymmetry after IFRS adoption. Abad et al. (2017) applied market microstructure proxies for information asymmetry measurement to examine the effects of IFRS adoption in the Spanish stock market. They found information asymmetry reduced after IFRS adoption. Finally, Turki et al. (2017) same as Armstrong et al. (2008) and Preiato, Brown and Tarca (2009) found IFRS/IAS reduces significantly the information asymmetry level in EU countries.

However, there are some studies that show an insignificant relationship between IFRS and information asymmetry. Since information asymmetry is the most important factor of earnings management, Jeanjean and Stolowy (2008) for instance, found earnings management is increased after IFRS adoption in Australia, France, and the UK. They also found IFRS was not a major factor of improvement in terms of financial information quality. In the case of 20 countries that adopted IFRS in 2005, Ahmed et al. (2013) documented more earnings management, less timely loss recognition, and more earnings smoothing after the adoption of IFRS. Kao and Wei (2014) found IFRS can improve information asymmetry but did not find a positive result for the quality of accounting information in China. Similarly, Timm et al. (2016) also found a higher level of earnings management after IFRS adoption in Latin America.

According to this literature review, past empirical studies show mixed findings of the impact of IFRS adoption on information asymmetry. For example, some studies found a reduction in information asymmetry following the IFRS adoption, while similar studies in other countries show the opposite. This indicates that the effect of IFRS adoption could be contingent upon other factors such as the financial environment and background of adopter countries. Therefore, it is difficult to conclude whether IFRS adoption drives information asymmetry reduction or not. The mixed evidences provide an opportunity to shed further light on the debate surrounding the effects of IFRS and examine whether IFRS can benefit developing countries through information asymmetry improvement. The mixed evidences also provide an opportunity for further studies by examining whether IFRS adoption can benefit developing countries in the same way as developed countries or considering their transitional economies, less market efficiency, and weak legal enforcement, their local accounting standards benefit them more. This study, therefore, investigates the impact of IFRS adoption on information asymmetry incorporating different backgrounds of adopter countries. 
This study adds to the knowledge by examining this relationship between ASEAN-6 countries consist of Indonesia, Malaysia, Philippines, Singapore, Thailand, and Vietnam.

Past studies have employed several theories to provide justification for IFRS adoption by developing countries. The theories include the economic theory of networks, isomorphism theory, and agency theory. According to the economic theory of network, developing countries in same region are likely to implement IFRS if they found that other countries in the region are IFRS adopter and have benefited from the adoption (Ramanna \& Sletten 2009; Samaha \& Khlif 2016), while the isomorphism theory posits that countries are motivated to adopt IFRS as some institutions such as the International Monetary Fund (IMF) provide foreign aid with the requirement of IFRS adoption (Judge, Li \& Pinsker 2010; Samaha \& Khlif 2016). The agency theory suggests that countries implement IFRS because they believe that more disclosure will lead to reduce agency cost and information asymmetry thus attract more investors (Al-Akra, Eddie \& Ali 2010). Another theory that can be used to explain IFRS adoption is the signaling theory. According to the signaling theory, countries are likely to make the decision to implement IFRS because they believe that IFRS provides a strong signal to the investors that the companies in those countries will provide more meaningful and transparent accounting information than otherwise would be the case (Gordon et al. 2012). This study applies agency theory to explain the relationship between IFRS and information asymmetry.

Agency theory is concerned with solving two problems that can occur in an agency relationship between the principal (investors) and agent (company) (Eisenhardt 1989). The first problem arises when there is a conflict between the goals or desires of the principal and the agent. It is difficult or expensive for the principal to verify what the agent behaves in a manner that would result in maximizing the interest of the principal. The second problem arises when the principal and agent have different attitudes toward risk because of the differences in risk preferences. Indeed, according to Jensen and Meckling (1976) agency theory asserted that with the presence of information asymmetry, the agent (companies) is likely to pursue interests that may hurt the principal (investors). Based on agency theory, lack of information causes information asymmetry problem (Verrecchia 2001) and information asymmetry problem causes investors to undervalue companies and to become less willing to invest (Dhaliwal et al., 2011). Indeed, with the presence of information asymmetry problem, illiquidity increases, the differences between bid and ask increase or liquidity decreases (Verrecchia 2001; Amihud 2002; Yaacob et al. 2017). This assertion of the agency theory addresses the probability that IFRS implementation may affect information asymmetry reduction, as IFRS adoption lead to increase financial information quality, comparability, and transparency. Therefore, based on the above arguments, this study uses agency theory as the theory to explain the relationship between IFRS and information asymmetry. In line with the assertion of agency theory, this study hypothesizes that:

IFRS is negatively associated with information asymmetry.

\section{RESEARCH METHOD}

This study applies a panel data research design and employs Ordinary Least Square (OLS) and Generalized Moment Method (GMM) estimation techniques. In order to test the hypothesis, 2 regression models are utilized. The first model examines the effects of IFRS using dummy variables and IFRS compliance level to explore statistic effect of IFRS on information asymmetry in ASEAN-6 countries. The second model considers the dynamic effect of IFRS using dummy variables and IFRS compliance level, on information asymmetry in ASEAN-6 countries. To the extent that IFRS leads to information asymmetry reduction, $\beta_{1}$ is expected to be negative and significant in models. The regression models are utilized;

$$
\begin{aligned}
& \text { Illiquidity/Bid }- \text { Ask }_{i, t}=\beta_{0}+\beta_{1} \text { IFRS Dummy/IFRS LEVEL } L_{i, t}+\beta_{2} \text { Size }_{i, t}+\beta_{3} \text { Leverage }_{i, t}+\quad \text { Static } \\
& \beta_{4} \text { Profit }_{i, t}+\beta_{5} \text { Growth }_{i, t}+\beta_{6} \text { Turnover }_{i, t}+\varepsilon_{i, t} \quad \text { Panel }
\end{aligned}
$$

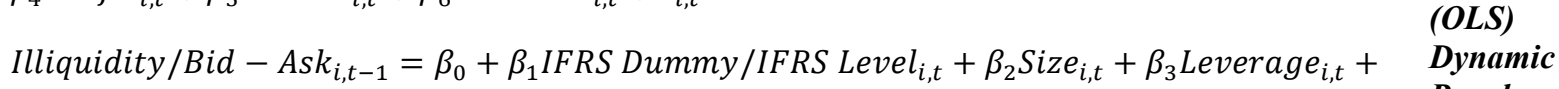

$$
\begin{aligned}
& +\beta_{4} \text { Profit }_{i, t}+\beta_{5} \text { Growth }_{i, t}+\beta_{6} \text { Turnover }_{i, t}+\varepsilon_{i, t}
\end{aligned}
$$

Where; Illiquidity Bid-Ask IFRS

Size
Is information asymmetry measured by Amihud (2002) Is information asymmetry measured in Bid-Ask Spread IFRS required/permitted, the value of 1 if the IFRS is required/ permitted by countries and 0 otherwise, IFRS compliance level which scored based on Table 1 Is natural logarithm of total assets 
Leverage

Profit

Growth

Turnover
Is the ratio of total debt to total equity

Is the ratio of return on assets

Is the ratio of book value of equity to market value

Is the natural logarithm of trading volume divided by the market value

This study investigates on the relationship between IFRS and Information Asymmetry. Therefore, the dependent variable for this study is information asymmetry and independent variable is IFRS. This study uses two different measurements for IFRS, which are the dummy variable (IFRS Dummy) and IFRS compliance Level (IFRS Level). For IFRS Dummy, the value of 1 is given if IFRS is required or permitted by a country while the value of 0 is given if otherwise. For IFRS compliance level (IFRS Level), this study employs scores measured on a $0-7$ scale. The scores were constructed based on characteristics that are stated by IFRS Foundation's Jurisdictional Profiles (IASB 2016) which is presented in Table 1.

TABLE 1. IFRS compliance level

\begin{tabular}{cl}
\hline Level & \multicolumn{1}{c}{ Characteristics } \\
\hline 1 & $\begin{array}{l}\text { Has the jurisdiction made a public commitment in support of moving towards a single set of high- } \\
\text { quality global accounting standards? }\end{array}$ \\
2 & $\begin{array}{l}\text { Has the jurisdiction made a public commitment towards IFRS standards as that single set of high- } \\
\text { quality global accounting standards? }\end{array}$ \\
3 & $\begin{array}{l}\text { For domestic companies are IFRS standards REQUIRED or PERMITTED? } \\
\text { Are IFRS standards also required or permitted for more than the consolidated financial statements of } \\
\text { companies whose securities trade in a public market? }\end{array}$ \\
& $\begin{array}{l}\text { Are all or some foreign companies whose securities trade in a public market either REQUIRED or } \\
\text { PERMITTED to use IFRS standards in their consolidated financial statements? }\end{array}$ \\
& Are IFRS standards incorporated into law or regulations? \\
& Has the jurisdiction adopted the IFRS for SMEs standards for at least some SMEs?
\end{tabular}

The reliability of a measure indicates to which it is without bias and hence ensure consistent measurement across time and across the various items in the instrument (Sekaran \& Bougie 2016). In order to avoid biases in the scoring and testing the reliability of IFRS compliance level scores, this study applies test-retest reliability introduced by Sekaran and Bougie (2016). Test-retest reliability measures test stability and consistency and help to assess the goodness or biases of a measure. Specifically, this study uses Inter-rater Reliability where the same test is carried out more than once with different people as raters to see if the scores are the same. Therefore, this study scores the IFRS level of compliance three times, first by the researcher of this study and twice more by other researchers in the area of accounting and financial reporting ${ }^{2}$. Table 2 illustrates the researchers' score of level of IFRS compliance. As can be seen from the table, the score given were almost the same, with $93 \%$ rate of agreement. Therefore, it can be concluded that the scores for IFRS level of compliance are reliable.

As mentioned before, Indonesia and Vietnam have not adopted IFRS yet. However as seen in Table 3, Indonesia, unlike Vietnam, has a public commitment towards IFRS as a single set of high-quality global accounting standards. Therefore, Indonesia gains 2 scores of IFRS Level of Compliance.

TABLE 2. Inter- Rater Reliability

\begin{tabular}{|c|c|c|c|c|c|}
\hline ASEAN Countries & Researcher & Scorer 1 & Scorer 2 & Agreement & Level of Agreement \\
\hline Cambodia & 7 & 7 & 7 & $3 / 3$ & $100 \%$ \\
\hline Indonesia & 2 & 2 & 2 & $3 / 3$ & $100 \%$ \\
\hline Laos & 3 & $3 *$ & $4^{*}$ & $2 / 3$ & $67 \%$ \\
\hline Malaysia & 7 & 7 & 7 & $3 / 3$ & $100 \%$ \\
\hline Myanmar & 6 & 6 & 6 & $3 / 3$ & $100 \%$ \\
\hline Philippines & 7 & 7 & 7 & $3 / 3$ & $100 \%$ \\
\hline Singapore & 6 & 6 & 6 & $3 / 3$ & $100 \%$ \\
\hline Thailand & 4 & $3 *$ & $4 *$ & $2 / 3$ & $67 \%$ \\
\hline Vietnam & 0 & 0 & 0 & $3 / 3$ & $100 \%$ \\
\hline Total & & & & & $93 \%$ \\
\hline
\end{tabular}


Each ASEAN country has a different starting year of IFRS compliance (IFRS Foundation's Jurisdictional Profiles (IASB, 2016)), therefore, this study applies the dummy and level scores based on the starting year for each country. Table 3 presents the starting year of IFRS compliance for ASEAN countries.

TABLE 3. Starting year of IFRS implication

\begin{tabular}{clcc}
\hline No & ASEAN & $\begin{array}{c}\text { Starting year of IFRS adoption (IFRS } \\
\text { Dummy) }\end{array}$ & $\begin{array}{c}\text { Starting year of IFRS compliance } \\
\text { (IFRS Level) }\end{array}$ \\
\hline 1 & Brunei & 2014 & 2014 \\
2 & Cambodia & 2012 & 2012 \\
3 & Indonesia & - & 2012 \\
4 & Laos & 2013 & 2013 \\
5 & Malaysia & 2012 & 2010 \\
6 & Myanmar & 2011 & 2011 \\
7 & Philippines & 2010 & 2008 \\
8 & Singapore & 2012 & 2009 \\
9 & Thailand & 2014 & 2014 \\
10 & Vietnam & - & - \\
\hline
\end{tabular}

Information asymmetry occurs when in an investment, the company has more and better information than the investor. Companies transact with liquidity-motivated investors or uninformed investors and with illiquiditymotivated or informed investors. Companies gain profit from transactions with uninformed investors because they are trading against the companies' spread. And companies lose profit from transactions with informed investors because they collect private information about company value before trading, therefore prevailing information asymmetry and illiquidity in the pricing process (Nagar, Schoenfeld and Wellman, 2019).

To the extent that information asymmetry may decrease under IFRS, this should be reflected in measures of information asymmetry such as Bid-ask Spread and Illiquidity measure developed by Amihud (2002), the Probability of Informed Trading (PIN) of Easley et al. (1996), the Volume-synchronized Probability of Informed Trading (VPIN) of Easley et al. (2012). Most of the information asymmetry measurement, however, requires a lot of microstructure data that are not available in many stock markets. And, even when available, the data does not cover very long periods of time. Therefore, taking into consideration the unavailability of data, this study analyses information asymmetry using only Bid-Ask Spread and the Illiquidity measurements.

Bid-Ask Spread (Bid-Ask) is difference between the highest price of a stock that investor is willing to pay (bid price) and the lowest price of a stock that is acceptable by companies (ask price) (Leuz \& Verrecchia 2000). This difference provides compensation to the inyestors who risk in their investment and ensure capital market liquidity. In general, the less Bid-Ask equals to more market liquidity. In other words, the existence of information asymmetry between companies and investors leads to higher Bid-Ask or higher difference between Bid and Ask prices or less liquidity.

The Bid-Ask contains order processing cost, inventory-holding cost and adverse selection cost (Callahaa, Lee and Yahn, 1997). Order processing cost is the cost spent by traders to settle clearing transactions. Inventoryholding cost is the cost spent by traders to hold a number of shares to fulfill investor demand. Adverse selection cost is the cost requested by companies because they accept the risk when involved in transactions with informed investors. Adverse selection costs arise from the companies' informational disadvantage or information asymmetry in the transaction with informed investors.

Companies create spreads between bids and ask prices to maximize the difference between profit from transactions with uninformed investors and loss from transactions with informed investors. Or in other words, when companies find that transactions with informed investors are increasing, they will spread the adverse selection cost, thus liquidity will reduce or information asymmetry will occur (Callahaa, Lee and Yahn, 1997). Therefore, Bid-Ask is used as one of the information asymmetry measurements by this study. Consistent with past studies Bid-Ask is estimated as follows; 


$$
\text { BidAsk }_{i t}=\frac{\text { AskPrice }- \text { BidPrice }}{\left[\frac{\text { AskPrice }+ \text { BidPrice }}{2}\right]}
$$

\section{ILLIQUIDITY}

In reacting with informed investors companies supply their own disclosure. However, since investors and companies are self-interest agents, there is a possibility that they alter the company's uncertainty for their benefit. (Core 2001; Nagar et al. 2018). Informed investors have a positive and significant effect on stock returns. If informed investors anticipate higher market illiquidity, they will price stocks, therefore, they expect a higher stock return (Amihud, 2002). Barry \& Brown (1984) proposed that the higher stock return is compensation of investors' less information compared with companies' more information. Therefore, can be concluded that illiquidity will increase in the asymmetry of information between companies and investors (Glosten \& Milgron 1985; Kyle 1985; Amihud 2002; Amihud et al. 2015). Therefore, this study employs illiquidity measurement introduced by Amihud (2002) which measures the sensitivity of stock price to dollar trading volume to measure information asymmetry (Amihud et al. 2015; Abad et al. 2017; Hur \& Chung 2018). The Illiquidity is estimated as follows;

$$
\text { Illiquidity }_{\text {idt }}=\sum_{t=1}^{i d t} \frac{\mid \text { Return }_{\text {idt }} \mid}{(\text { dollar }) \text { trading volum }_{\text {idt }}}
$$

Stock Illiquidity is defined here as the average ratio of the daily absolute return to the (dollar) trading volume on that day. Return $n_{i d t}$ is the return on stock $i$ on day $d$ of year $t$ and (dollar) trading volum idt $_{\text {is }}$ the respective daily volume in dollars. The higher value of Illiquidity means the market is less liquid and higher information asymmetry problem. This study uses monthly data for information asymmetry measurements to cover excel limitations. Only monthly data for each company in every ASEAN country which verifies as positive and non-zero were used. To transform monthly data into yearly data, the mean values of the monthly data are used.

Similar to prior studies, this study employs several control variables because of the possible association between these variables and the dependent variable. The control variables which are applied by this study consist of company size, leverage, profitability, growth opportunity, and turnover. Company size has been used as an indicator of the importance of the company's internal control systems (Defond \& Jiambalvo 1994). Previous studies found large companies usually produce more information of better quality than smaller companies and their activities are monitored more closely by financial analysts, which could limit the earnings management (Tsamenyi, Adu \& Onumah 2007; Naranjo et al. 2013; Neel 2017). Consequently, the information asymmetry problem is likely to be lower in large companies compared to small companies. Therefore, this study predicts that company size has a negative association with information asymmetry. To measure company size, this study applies the logarithm of total assets. This measure is also used by Naranjo et al. (2013), Neel (2017) and Abad et al. (2017). Leverage is important for several reasons. First, a highly leveraged company is more likely to enforce a greater degree of manipulation in the accounts and this introduces noise into the information content of the income stream (Watts and Zimmerman, 1986). Secondly, according to Christie (1982), as companies' leverage increases, the volatility of the impact of news increases, and this impacts upon the value of a company's equity. Consequently, an increase in the financial leverage ratio contributes to lower financial information quality. Therefore, this study expects leverage to be positively associated with information asymmetry. In line with Naranjo et al. (2013), Neel (2017) and Abad et al. (2017), leverage is measured as the ratio of total debt to total equity.

Profitability is a company characteristic that affects financing decisions (Naranjo et al. 2013; Utama et al. 2016). According to Welker (1995) disclosure policy is expected to have a great impact on profitability. It can be concluded that companies which are more profitable may have less information asymmetry problem (H. Daske, Hail, Leuz \& Verdi 2013). This study expects that profitability has a negative association with information asymmetry. Profitability is measured as return on assets (ROA). This measure is also used by Utama et al. (2016) and Abad et al. (2017). Growth opportunity like profitability is also a company characteristic which affects financing decisions (Naranjo et al. 2013; Utama et al. 2016). According to Daske et al. (2013) managers in large and more profitable companies with larger growth opportunities, have more dispersed ownership structures to have stronger incentives for transparent financial reporting. Therefore, this study expects that growth opportunity has a negative association with information asymmetry. Growth opportunity is measured as the ratio of the book value of equity to market value (BTM). This measure is also used by Utama et al. (2016) and Abad et al. (2017). This study also includes share 
turnover as a control variable. The microstructure literature shows that more frequently traded companies are more liquid as well as suffer lower information asymmetry problems (Easley, Nicholas, O'Hara \& Paperman 1996; Liu, Luo \& Wang 2017; Abad et al. 2017). Therefore, this study expects that turnover has a negative association with information asymmetry. Turnover is the natural logarithm of trading volume divided by the market value. This measure is also used by Liu et al. (2017) and Abad et al. (2017).

\section{SAMPLE SELECTION}

This study uses ASEAN countries as sample. ASEAN countries consist of ten members, Brunei, Cambodia, Indonesia, Malaysia, Myanmar, Laos, Philippines, Singapore, Thailand and Vietnam. All ASEAN companies are potential sample of this study for measuring information asymmetry. However, some restrictions need to be imposed in the sample selection process. First, companies, which do not have needed data for each information asymmetry measurements, are excluded. Second, companies with Zero and Negative value after information asymmetry measurement, as well as outliers, are excluded.

Data for this study was collected from 2001 to 2018. This study uses 2001 as the starting year for data collection as it is the year that data became available in database for information asymmetry. However, because of availability of data for information asymmetry measurement, Brunei Darussalam, Laos, Cambodia and Myanmar are excluded from this analysis. As well as, the information asymmetry measurements data are available from 2008 for Vietnam. Therefore, the total sample for information asymmetry measurements consist ASEAN-6 and a total of 29,702 (company-year) unbalanced observations after omitting not available data and data with negative sign. Table 4 presents the summary of data collections.

TABLE 4. Data collection for information asymmetry measurements

\begin{tabular}{|c|c|c|c|c|c|c|}
\hline \multirow[t]{2}{*}{ Countries } & \multicolumn{3}{|c|}{ Initial Observations } & \multicolumn{3}{|c|}{$\begin{array}{l}\text { Final Observations after Omitting NA } \\
\text { data and treatment of data }\end{array}$} \\
\hline & No of Observations & Company & Year & No & Company & Year \\
\hline Indonesia & 14,812 & 529 & 1991-2018 & 4,085 & 524 & $2001-2018$ \\
\hline Malaysia & 24,920 & 890 & $1991-2018$ & 8,738 & 848 & 2001-2018 \\
\hline Philippines & 6,888 & 246 & 1991-2018 & 2,566 & 235 & 2001-2018 \\
\hline Singapore & 20,944 & 748 & $1991-2018$ & 6,445 & 683 & $2001-2018$ \\
\hline Thailand & 18,844 & 673 & $1991-2018$ & 4,837 & 631 & 2002-2018 \\
\hline Vietnam & 22,232 & 794 & $1991-2018$ & 3,031 & 628 & 2008-2018 \\
\hline Total & 108,640 & 3,880 & 1991-2018 & 29,702 & 3,549 & -- \\
\hline
\end{tabular}

\section{DESCRIPTIVE STATISTICS}

Table 5 shows the descriptive statistics of the variables before and after IFRS. As can be seen, the mean value of Illiquidity decreased after IFRS, from 6.708 to 3.707. Similarly, the mean value of Bid-Ask also decreased after IFRS, from 0.042 to 0.032 . These outcomes reveal that IFRS implementation leads to increase in the market liquidity (IFRS has a negative and significant relationship with Bid-Ask) and market illiquidity reduction (IFRS has a negative and significant relationship with Illiquidity). The lower mean values of Illiquidity and Bid-Ask after IFRS are consistent with the findings of past studies (Naranjo et al. 2013; Turki et al. 2016; Abad et al. 2017). For control variables, mean values for size and growth opportunities were higher after IFRS, while mean values for leverage, profitability, and turnover were lower after IFRS.

TABLE 5. Descriptive statistics of variables before and after IFRS

\begin{tabular}{|c|c|c|c|c|c|c|}
\hline \multirow[b]{3}{*}{ Illiquidity } & \multicolumn{3}{|c|}{ Before IFRS } & \multicolumn{3}{|c|}{ After IFRS } \\
\hline & Mean & Max & Min & Mean & Max & Min \\
\hline & 6.708 & 99.990 & 0.001 & 3.707 & 99.747 & 0.001 \\
\hline Bid-Ask & 0.042 & 0.972 & 0.003 & 0.032 & 0.282 & 0.002 \\
\hline SIZE & 12.052 & 23.105 & 5.087 & 12.218 & 23.687 & 5.052 \\
\hline LEVERAGE & 11.111 & 26.239 & -0.847 & 10.690 & 22.347 & 0.192 \\
\hline TURNOVER & 0.246 & 109.775 & -0.001 & 0.199 & 57.514 & 0.003 \\
\hline
\end{tabular}




\begin{tabular}{lcccccc} 
PROFITABILITY & 1.127 & 186.158 & -187.29 & 0.753 & 193.647 & -235.56 \\
GROWTH & 1.847 & 923.848 & -139.59 & 3.818 & 315.98 & -90.753 \\
\hline
\end{tabular}

Notes: Illiquidity is information asymmetry measured by Amihud (2002), Bid-Ask is information asymmetry measured in Bid Ask Spread, IFRS required/permitted, the value of 1 if the IFRS is required/ permitted by countries and 0 otherwise, IFRS compliance level which scored based on Table 2, SIZE is natural logarithm of total assets, LEVERAGE is the ratio of total debt to total equity, PROFITABILITY is the ratio of return on assets, GROWTH is the ratio of book value of equity to market value, TURNOVER is the natural logarithm of trading volume divided by the market value.

Table 6 also provides the descriptive statistics for variables before and after outlier treatment. Panel A shows the descriptive statistics of all variables before outlier treatment and Panel B shows the descriptive statistics after outlier treatment. The differences between mean values, maximum and minimum values of panel A and panel B, demonstrate the effects of outlier treatments and omission of zero and negative values of all variables. According to Panel A (before outlier treatment), the mean value of Illiquidity is 36.495 , with a maximum value of 259.372 and a minimum value of 0.000 . According to Panel B (after outlier treatment), the mean value of Illiquidity is decreased to 5.557, and the maximum value is decreased to 99.990. As mentioned before, less Illiquidity value indicates less information asymmetry. Therefore, the mean values of Illiquidity present the average of market illiquidity. According to Panel B, the mean value of Illiquidity is decreased, which shows the effect of outlier treatment, the omission of zero and negative values on the average of market illiquidity. The mean value of Bid-Ask in Panel A (before outlier treatment) is 0.054 with a maximum value of 2.000 and a minimum value of -1.988 . According to Panel B (after outlier treatment), the mean value of Bid-Ask is decreased to 0.038 and the maximum value is decreased to 0.972 . As mentioned before, less Bid-Ask value indicates higher market liquidity which indicates less information asymmetry. Therefore, the mean values of Bid-Ask present the average of market liquidity. According to Panel B, the mean value of Bid-Ask is decreased, which shows the effect of outlier treatment, the omission of zero and negative values on the average of market liquidity.

TABLE 6. Descriptive statistics of variables before and after outlier treatment

\begin{tabular}{|c|c|c|c|c|c|}
\hline \multicolumn{6}{|c|}{ Panel A: Descriptive statistics of original data } \\
\hline & Mean & $\operatorname{Max}$ & Min & Skew & Kurt \\
\hline Illiquidity & 36.495 & 259.372 & 0.000 & 132.553 & 209.750 \\
\hline Bid-Ask & 0.054 & 2.000 & -1.988 & 4.141 & 56.855 \\
\hline SIZE & 11.779 & 23.673 & -5.424 & -0.572 & 10.850 \\
\hline LEVERAGE & 12.008 & 27.352 & -20.363 & -0.4471 & 7.649 \\
\hline TURNOVER & & 8072.650 & -9167.90 & -24.130 & 786.123 \\
\hline PROFITABILIT & 933.66 & 1584048 & -235.529 & 54.729 & 346.551 \\
\hline \multirow[t]{3}{*}{ GROWTH } & 639 & 9980.080 & -4912.450 & 42.993 & 426.410 \\
\hline & \multicolumn{2}{|c|}{ Total Observations } & \multicolumn{2}{|c|}{ IFRS Frequency } & Percent \\
\hline & \multicolumn{2}{|c|}{80,236} & \multicolumn{2}{|c|}{14,176} & $17.66 \%$ \\
\hline \multicolumn{6}{|c|}{ Panel B: Descriptive statistics after outlier treatment } \\
\hline & Mean & Max & Min & Skew & Kurt \\
\hline Illiquidity & 5.557 & 99.990 & 0.001 & 3.853 & 18.712 \\
\hline Bid-Ask & 0.038 & 0.972 & 0.002 & 3.751 & 26.181 \\
\hline SIZE & 12.112 & 23.687 & 5.052 & 0.793 & 4.256 \\
\hline LEVERAGE & 10.941 & 26.239 & -0.847 & 0.953 & 4.579 \\
\hline TURNOVER & 0.229 & 109.775 & -0.001 & 7.062 & 5.464 \\
\hline PROFITABILITY & 0.998 & 193.647 & -235.563 & 1.954 & 5.084 \\
\hline \multirow[t]{2}{*}{ GROWTH } & 2.502 & 923.848 & -139.596 & 3.190 & 11.069 \\
\hline & \multicolumn{2}{|c|}{ Final Observations } & \multicolumn{2}{|c|}{ IFRS Frequency } & Percent \\
\hline IFRS & \multicolumn{2}{|c|}{23,677} & \multicolumn{2}{|c|}{9,945} & $42 \%$ \\
\hline
\end{tabular}




\begin{abstract}
Notes: Illiquidity is information asymmetry measured by Amihud (2002), Bid-Ask is information asymmetry measured in Bid-Ask Spread, IFRS required/permitted, the value of 1 if the IFRS is required/ permitted by countries and 0 otherwise, IFRS compliance level which scored based on Table 2, Size is natural logarithm of total assets, Leverage is the ratio of total debt to total equity, Profit is the ratio of return on assets, Growth is the book value of equity to market value ratio, Turnover is the natural logarithm of trading volume divided by the market value.
\end{abstract}

Table 6 also indicates the frequency of IFRS before (Panel A) and after (Panel B) outlier treatment. As can be seen, before outlier treatment the IFRS frequency is around 18 percent of total observations, while the IFRS frequency after outlier treatment is increased to 42 percent. These results show that IFRS frequency has a higher proportion in panel B compared to panel A. These outcomes reveal that most of the not available data were from before IFRS implementation.

The normality of data distribution can be determined based on the descriptive statistics. The value of skewness and kurtosis provides an indication of the distribution of data. When the value for skewness is zero and the value of kurtosis is three, the distribution of data is said to be normal (Gujarati \& Porter 2009). Based on Panel A of Table 6, the values of skewness range from 132.553 to -24.130 while the values for kurtosis range from 786.123 to 7.649 , indicating a non-normal data distribution. Based on panel B of table 6 , after outlier treatments, the values of skewness range from 7.062 to 0.793 while the values for kurtosis range from 26.181 to 4.256 , also indicating a nonnormal data distribution. Univariate outliers were identified by examining the value of z-score of a variable, and multivariate outliers were identified according to the value of Mahalanobis distance (Tabachnick \& Fidell 2007). As the observations for this study were large, all outliers were treated by way of elimination, in line with Tabachnick and Fidell (2007). The values for skewness and kurtosis after outlier treatment have improved significantly. According to Hayes (2013) normality is one of the least important in linear regression analysis, thus, the non- normal distribution of data in this study is not likely to be an issue. Moreover, the central limit theorem states that the sampling distribution of any statistic will be normal or nearly normal, if the sample size is large enough (Gujarati 2003). Additionally, past studies argue that non-normality is not a significant concern when involving financial data as a non-normal distribution has been accepted as a stylized fact for studies in taking financial data (Abdul-Rahim 2011).

\title{
MULTICOLLINEARITY
}

Table 7 provides the correlation matrix between variables. The presence of multicollinearity could affect the precision of multiple regression analysis as it makes the estimates of regression coefficients unreliable. The correlation values of less than 0.8 show that there is no collinearity issue among variables (Gujarati \& Porter 2009). As can be seen in Table 7, it can be concluded that there is no serious multicollinearity issue since the correlations between micro variables are less than 0.8 .

\begin{tabular}{|c|c|c|c|c|c|c|c|c|}
\hline & Illiquidity & IFRS D & IFRS L & SIZE & LEV & PROFIT & TURNO & GROW \\
\hline \multicolumn{9}{|l|}{ Illiquidity } \\
\hline \multicolumn{9}{|l|}{ IFRS D } \\
\hline IFRS L & $-0.102 *$ & 0.642 & 1.000 & & & & & \\
\hline SIZE & $-0.074 *$ & $0.044 * *$ & $0.046^{* *}$ & 1.000 & & & & \\
\hline LEVERAGE & $0.103 *$ & $-0.057 * *$ & -0.177 & 0.709 & 1.000 & & & \\
\hline PROFIT & $-0.047 * *$ & $-0.028 * *$ & $0.047 * *$ & 0.119 & $0.017 * * *$ & 1.000 & & \\
\hline TURNOVER & $-0.009 * * *$ & $-0.020 * *$ & $-0.006 * * *$ & -0.154 & -0.140 & $-0.039 * *$ & 1.000 & \\
\hline \multirow[t]{2}{*}{ GROWTH } & $-0.004 * * *$ & $0.014 * * *$ & $0.011 * * *$ & $-0.027 * *$ & $-0.009 * * *$ & $-0.012 * *$ & $0.077^{*}$ & 1.000 \\
\hline & BID-ASK & IFRS D & IFRS L & SIZE & LEV & PROFIT & TURNO & GROW \\
\hline BIDASK & 1.000 & & & & & & & \\
\hline IFRS D & $-0.073 *$ & 1.000 & & & & & & \\
\hline IFRS L & $0.059 * *$ & 0.642 & 1.000 & & & & & \\
\hline SIZE & -0.311 & $0.044 * *$ & $0.046^{* *}$ & 1.000 & & & & \\
\hline LEVERAGE & $-0.104 *$ & $-0.057 * *$ & -0.177 & 0.709 & 1.000 & & & \\
\hline
\end{tabular}




\begin{tabular}{|c|c|c|c|c|c|c|c|}
\hline PROFIT & $-0.102 *$ & $-0.028 * *$ & $0.047 * *$ & 0.119 & $0.017 * * *$ & 1.000 & \\
\hline TURNOVER & $0.101 *$ & $-0.020 * *$ & $-0.006 * * *$ & -0.154 & -0.140 & $-0.039 * * *$ & 1.000 \\
\hline GROWTH & $0.007 * * *$ & $0.014 * *$ & $0.011 * * *$ & $-0.027 * *$ & $-0.009 * * *$ & $-0.012 * * *$ & $0.077 * *$ \\
\hline
\end{tabular}

Notes: $*, * *, * * *$ represent significance at the 10, 5 and 1 percent levels, respectively. Illiquidity is information asymmetry measured by Amihud (2002), Bid-Ask is information asymmetry measured in Bid-Ask Spread, IFRS required/permitted, the value of 1 if the IFRS is required/ permitted by countries and 0 otherwise, IFRS compliance level which scored based on Table 2 , SIZE is natural logarithm of total assets, LEVERAGE is the ratio of total debt to total equity, PROFIT is the ratio of return on assets, GROWTH is the ratio of book value of equity to market value, TURNOVER is the natural logarithm of trading volume divided by the market value.

\section{ORDINARY LEAST SQUARE (OLS) FINDINGS}

Table 8 presents the OLS regression results of the relationship between IFRS and information asymmetry. Consistent with the hypothesis, the findings show that IFRS dummy is negatively associated with information asymmetry measured by Illiquidity at 1 percent level with a coefficient value of -0.479 and t-statistic value of -3.200 . The findings also show that IFRS dummy is negatively associated with information asymmetry measured by Bid-Ask at 1 percent level with a coefficient value of -0.011 and $t$-statistic value of -13.568 . The results reveal that the level of information asymmetry is reduced after IFRS was required/permitted.

Similarly, IFRS Compliance Level (IFRS Level) is negatively associated with information asymmetry measured by Illiquidity at 10 percent level with a coefficient value of -0.043 and $t$-statistic value of -1.657 . The findings also show that IFRS Level is negatively associated with information asymmetry measured by Bid-Ask at 10 percent level with a coefficient value of -0.002 and t-statistic value of -1.740 . The results reveal that the level of information asymmetry is increased after ASEAN-6 countries' compliance with IFRS. The findings substantiate several past findings (Naranjo et al. 2013; Turki et al. 2016; Abad et al. 2017) that IFRS leads to improved financial reporting quality and market liquidity which reduces information processing costs, adverse selection cost, illiquidity and information asymmetry for capital market participants.

With respect to the control variables, Table 6 shows that the effect of control variables are consistent with the prediction of this study. For example, information asymmetry (Illiquidity and Bid-Ask) is negative and significant associated with size at 1 percent level. This finding is consistent with past studies (Tsamenyi et al. 2007; Naranjo et al. 2013; Neel 2017) that larger companies are more liquid and suffer lower information asymmetry problems. Information asymmetry (Illiquidity and Bid-Ask) was positive and significant associated with leverage at 1 percent level. This finding is also consistent with past studies (Naranjo et al. 2013; Abad et al. 2017) that companies with more leverage are more likely to have information asymmetry problem.

TABLE 8. The regression results for testing the relationship between IFRS and information asymmetry

\begin{tabular}{|c|c|c|c|c|c|c|c|}
\hline \multirow[b]{2}{*}{ Variables } & \multirow[b]{2}{*}{ Predi } & \multicolumn{3}{|c|}{ IFRS Dummy and Illiquidity } & \multicolumn{3}{|c|}{ IFRS Level and Illiquidity } \\
\hline & & Coef & t-Statc & Prob. & Coefficient & t-Stat & Prob. \\
\hline $\operatorname{IFRS}$ & - & $-0,479 * * *$ & -3.200 & 0.001 & $-0.043^{*}$ & -1.657 & 0.098 \\
\hline SIZE & & $0^{\prime}$ & -15.079 & 0.000 & $-2.169 * * *$ & -15.100 & 0.000 \\
\hline LEVERAGE & & $0.276 * * *$ & 4.692 & 0.000 & $0.271 * * *$ & 4.573 & 0.000 \\
\hline PROFIT & & 0.003 & 0.257 & 0.798 & 0.006 & 0.530 & 0.596 \\
\hline TURNOVER & - & -0.047 & -0.705 & 0.481 & -0.045 & -0.684 & 0.494 \\
\hline GROWTH & - & 0.003 & 1.035 & 0.301 & 0.003 & 1.053 & 0.292 \\
\hline $\operatorname{Adj} R^{2}$ & & 0.618 & & & 0.617 & & \\
\hline$F$-statistic & & $16.524 * * *$ & & & $16.514 * * *$ & & \\
\hline \multirow[t]{2}{*}{ Durbin-Watson } & & 1.558 & & & 1.556 & & \\
\hline & & \multicolumn{3}{|c|}{ IFRS Dummy and Bid-Ask } & \multicolumn{3}{|c|}{ IFRS Level and Bid-Ask } \\
\hline Variables & Predi & Coefficient & t-Statistic & Prob. & Coefficient & t-Stat & Prob. \\
\hline$I F R S$ & - & $-0.011 * * *$ & -13.568 & 0.000 & $-0.002 *$ & -1.740 & 0.082 \\
\hline$S I Z E$ & - & $-0.012 * * *$ & -15.948 & 0.000 & $-0.016 * * *$ & -19.369 & 0.000 \\
\hline LEVERAGE & + & $0.002 * * *$ & 7.334 & 0.000 & $0.002 * * *$ & 7.404 & 0.000 \\
\hline
\end{tabular}




\begin{tabular}{lcccc|ccc} 
PROFIT & - & $-0.003 * * *$ & -6.372 & 0.000 & $-0.003 * * *$ & -5.074 & 0.000 \\
TURNOVER & - & $-0.002 * * *$ & -4.715 & 0.000 & $-0.002 * * *$ & -4.835 & 0.000 \\
GROWTH & - & -0.005 & -0.332 & 0.740 & -0.005 & -0.305 & 0.761 \\
Adj $R^{2}$ & & 0.312 & & & 0.306 & & \\
F-statistic & & $5.357 * * *$ & & & $5.234 * * *$ & & \\
Durbin-Watson & 1.962 & & & 1.945 & & \\
\hline
\end{tabular}

Illiquidity/Bid - Ask $_{i, t}=\beta_{0}+\beta_{1}$ IFRS Dummy/IFRS LEVEL $L_{i, t}+\beta_{2}$ Size $_{i, t}+\beta_{3}$ Leverage $_{i, t}+\beta_{4}$ Profit $_{i, t}+$ $\beta_{5}$ Growth $_{i, t}+\beta_{6}$ Turnover $_{i, t}+\varepsilon_{i, t}$

\begin{abstract}
$*, * *, *$ Notes: $* *$ represent significance at the 10,5 and 1 percent levels, respectively. Illiquidity is information asymmetry measured by Amihud (2002), Bid-Ask is information asymmetry measured in Bid-Ask, IFRS required/permitted, the value of 1 if the IFRS is required/ permitted by countries and 0 otherwise, IFRS compliance level which scored based on Table 2, SIZE is natural logarithm of total assets, LEVERAGE is the ratio of total debt to total equity, PROFIT is the ratio of return on assets, GROWTH is the ratio of book value of equity to market value, TURNOVER is the natural logarithm of trading volume divided by the market value.
\end{abstract}

The adjusted $\mathrm{R}^{2}$ of models with Illiquidity are 0.61 and models with Bid-Ask is 0.31 . This means that 61 percent of the changes in information asymmetry measured by Illiquidity and 31 percent of changes in information asymmetry measured by Bid-Ask Spread can be explained by the applied explanatory variables. Although this adjusted $\mathrm{R}^{2}$ value seems to be high and inflated, this outcome is consistent with findings of several past studies such as Abad et al. (2017) when Illiquidity is used for information asymmetry measurement, the Adj $\mathrm{R}^{2}$ is 0.88 and Naranjo et al. (2013) the Adj $R^{2}$ is 0.83 . Therefore, the Adj $R^{2}$ is consistent with the past studies that have information asymmetry as the dependent variable. However, in order to resolve any hesitation, with regards to the high adjusted $\mathrm{R}^{2}$, according to Gujarati and Porter (2009), the following data examination was carried out. First, data of this study were rechecked to ensure there was no wrong entry. Second, after making sure that the values are genuine, re-checking of multicollinearity was carried out. As can be seen from the correlation matrix presented in Table 7, there is no multicollinearity problem. Lastly, to ensure the accuracy of the model, the F-Statistic of the model is checked. Generally, a significant F-statistic of a model indicates whether the model is specified properly or not. As can be seen in Table 8, the F-statistic for the model is significant in $1 \%$ level. Therefore, although this study has a high adjusted $\mathrm{R}^{2}$, it is not due to any mistakes in data entry.

For further understanding the effect of IFRS on information asymmetry, it might be necessary to examine the IFRS effect on information asymmetry reduction in 6 ASEAN countries separately. For this reason, this study applies regression models for each country separately. Tables 9 shows the results of the relationship between IFRS (Dummy \& Level) and information asymmetry (Bid-Ask \& Illiquidity) in Indonesia (IFRS level), Malaysia, Philippines, Singapore, and Thailand. Indonesia is included due to that this country has a commitment to adopt IFRS. Vietnam is not included because it has not required or permitted IFRS yet. And the results are in line with the main results of this study which IFRS affects information asymmetry reduction.

TABLE 9. The results of relationship between IFRS and information asymmetry (ASEAN-5 separate)

\begin{tabular}{llccc|ccc}
\hline \multirow{2}{*}{ ASEAN-6 } & & \multicolumn{3}{c}{ Illiquidity } & \multicolumn{3}{c}{ Bid-Ask } \\
\cline { 3 - 8 } & IFRS & Coef & t-Stat & Prob & Coef & t-Statistic & Prob. \\
\hline Indonesia & IFRS Level & $-0.072^{*}$ & -1.873 & 0.061 & $-0.009^{* * *}$ & -7.503 & 0.000 \\
\hline Malaysia & IFRS Level & $-0.017^{* * *}$ & -3.487 & 0.001 & $-0.001 * * *$ & -3.618 & 0.000 \\
& IFRS Dummy & $-0.116^{* * *}$ & -3.402 & 0.001 & $-0.005^{* * *}$ & -4.929 & 0.000 \\
\hline Philippines & IFRS Level & $-0.222^{* * *}$ & -16.205 & 0.000 & $-0.008^{* * *}$ & -9.047 & 0.000 \\
& IFRS Dummy & $-1.411^{* * *}$ & -15.574 & 0.000 & $-0.048^{* * *}$ & -8.064 & 0.000 \\
\hline Singapore & IFRS Level & $-0.028^{* * *}$ & -3.403 & 0.001 & $-0.001^{*}$ & -1.622 & 0.105 \\
& IFRS Dummy & $-0.081^{* *}$ & -2.071 & 0.038 & $-0.006^{* * *}$ & -2.786 & 0.005 \\
\hline Thailand & IFRS Level & $-0.176^{* * *}$ & -11.880 & 0.000 & $-0.003^{* * *}$ & -6.149 & 0.000 \\
& IFRS Dummy & $-0.529^{* * *}$ & -11.880 & 0.000 & $-0.009^{* * *}$ & -6.149 & 0.000 \\
\hline
\end{tabular}

Notes: *,**** represent significance at the 10,5 and 1 percent levels, respectively. 
As can be seen in Table 9, IFRS compliance leads to information asymmetry (Bid-Ask) reduction in Indonesia. As mentioned before, Indonesia has not required or permitted IFRS, however, Indonesia made a public commitment in support of moving towards IFRS as the single set of high-quality global accounting standards from 2012. Therefore, this study scored Indonesia at 2 for the IFRS level of compliance. The results suggest that Indonesia would benefit greatly from IFRS adoption.

\section{GENERALIZED MOMENT METHOD (GMM) FINDINGS}

The relationship between IFRS and information asymmetry is dynamic, as agency problem and necessity of financial information quality contribute to promoting the financial reporting standards. Additionally, there may exist the endogeneity problem because IFRS may affect information asymmetry reduction while reducing in information asymmetry may also affect IFRS implementation decisions by non-adopter countries. Therefore, this study takes into consideration the dynamic nature as well as the endogeneity problem and examines the effect of IFRS on information asymmetry by using the GMM estimation technique. This study applies GMM as an additional test, which is more appropriate for dynamic associations, endogeneity, and autocorrelation problem-solving.

As mentioned before, in examining the relationship between IFRS and information asymmetry, there may exist the endogeneity problem that is not addressed via the use of the OLS estimator. According to Nickell (1981), the presence of individual-specific effects lagged dependent variable and potential endogeneity of independent variables makes the traditional panel estimators such as OLS inappropriate. One solution which is also introduced by past studies to solve the potential endogeneity problem is the GMM estimator. In addition to solving the endogeneity problem, GMM is also used to solve heteroscedasticity and autocorrelation. Therefore, GMM can be considered as a more complete measurement estimator than OLS. Since, the GMM estimator is designed for a situation with small timeseries and large cross-section, hence it may be appropriate for this study which focuses on ASEAN-6.

In all the GMM types (One-Step difference-GMM, Two-Step difference-GMM, One-Step system-GMM, and Two-Step system-GMM), four important assumptions need to be considered. 1) The number of instruments should be less than the number of observations. 2) The dynamic effect, lag dependent should be less than 1 and significant. 3) The null hypothesis of no autocorrelation in AR (2) must be failed to reject ( $p$-value $>0.05)$. 4) The Sargan or Hansen test of over-identification restriction must be failed to reject ( $p$-value $>0.05)$.

The results of GMM (One-Step System-GMM) are demonstrated by Table 10. As can be seen, the results are in line with the main results of this study which IFRS affects information asymmetry reduction. The results of IFRS dummy and information asymmetry measured by Illiquidity and Bid-ask, demonstrate that IFRS dummy is negatively associated with information asymmetry in ASEAN-6 countries. The results also demonstrate that the level of IFRS compliance is negatively associated with information asymmetry in ASEAN-6 countries.

TABLE 10. GMM results of relationship between IFRS and information asymmetry

\begin{tabular}{lcccc}
\hline \multirow{2}{*}{ Variables } & \multicolumn{2}{c}{ One-Step System-GMM } & \multicolumn{2}{c}{$\begin{array}{c}\text { One-Step System-GMM } \\
\text { IFRS Level }\end{array}$} \\
\cline { 2 - 5 } Illiquidity & Coefficient & $\mathrm{P}-\mathrm{V}$ & Coefficient & $\mathrm{P}-\mathrm{V}$ \\
L1. & $0.911^{* * *}$ & 0.000 & $0.912^{* * *}$ & 0.000 \\
IFRS & $-0.045^{* *}$ & 0.010 & $-0.004^{*}$ & 0.096 \\
SIZE & 0.011 & 0.121 & 0.009 & 0.215 \\
Leverage & -0.035 & 0.167 & -0.035 & 0.166 \\
Profitability & $0.087^{* *}$ & 0.022 & $0.089^{* *}$ & 0.020 \\
Turnover & $-0.144^{* *}$ & 0.012 & $-0.041^{* * *}$ & 0.000 \\
Growth & $0.004^{* *}$ & 0.020 & $0.004^{* *}$ & 0.019 \\
P(AR2) & 0.866 & & 0.926 & \\
\hline Bid-Ask & & & & 0.000 \\
L1. & $0.349^{* * *}$ & 0.000 & $0.356^{* * *}$ & 0.018 \\
IFRS & $-0.011^{* * *}$ & 0.000 & $-0.001^{* *}$ & 0.035 \\
SIZE & $-0.015^{* *}$ & 0.043 & $-0.014^{* *}$ & 0.792 \\
Leverage & -0.001 & 0.964 & -0.000 &
\end{tabular}




\begin{tabular}{lcccc} 
Profitability & $-0.008^{* *}$ & 0.035 & $-0.001^{* *}$ & 0.018 \\
Turnover & $0.015^{* * *}$ & 0.000 & $-0.015^{* * *}$ & 0.000 \\
Growth & $0.003^{* *}$ & 0.020 & $0.002^{* *}$ & 0.023 \\
$P\left(A R_{2}\right)$ & 0.866 & & 0.926 & \\
\hline
\end{tabular}

Notes: $*, * * * * *$ represent significance at the 10,5 and 1 percent levels, respectively.

\section{SUMMARY AND CONCLUSION}

This study analyzes the specified linear regression models using Ordinary Least Square (OLS), and Generalized Moment Method (GMM) to test hypothesis on a sample of South East Asian Nations (ASEAN). ASEAN is a regional political and economic grouping made up of Brunei Darussalam, Cambodia, Laos, Indonesia, Malaysia, Myanmar, the Philippines, Singapore, Thailand, and Vietnam. However, due to availability of data for information asymmetry measurement, the final sample of this study considered ASEAN-6 excluding Brunei, Cambodia, Laos, and Myanmar. The main variables of this study are IFRS, and information asymmetry. This study applies IFRS Dummy and IFRS Level as proxies for IFRS. Information asymmetry is used as the dependent variable. Due to the non-availability of data, this study analyses information asymmetry using only the Bid-Ask spread (Bid-Ask) and the Illiquidity measured by Amihud. The Bid-ask spread (Bid-Ask) is a proxy for information asymmetry which is commonly used by most previous studies. The Illiquidity measure is commonly applied to capture the price impact of transactions, to describe the arrival of new information to market participants. Moreover, several control variables were employed to reduce the potential measurement and model specification errors.

Two regression models were employed for analysing panel data. OLS is applied as the main estimation technique and GMM is applied as an additional test to corroborate the main findings. The results of both OLS and GMM, suggest that the level of information asymmetry is reduced after IFRS was required/permitted. These findings are consistent with the assertion of agency theory. The agency theory suggests that countries implement IFRS because they believe that more transparency and more disclosure will lead to reducing agency cost and information asymmetry. Therefore, this study supports the choice of IFRS implementation for ASEAN-6 countries as it drives the information asymmetry reduction.

There are costs related to implementation of new accounting standards to countries, therefore, the results of this study on effect of IFRS on information asymmetry help policy maker, regulators to understand the benefits that are brought by IFRS. Findings of this study also should be interest of policy maker of countries that have not required IFRS, due to this study provides an empirical document regarding the positive effect of IFRS from the aspects of information asymmetry reduction.

As with all empirical studies, this study has limitation. There are empirical studies in literature, which examined the determinants of information asymmetry reduction; however, this study was not able to utilize all those determinants as control variables. Therefore, this study suggests that for future study more control variables are taken into consideration. According to the past studies, information asymmetry is one of the important factors to explain the capital flows and this study only applied to measurement for information asymmetry (Bid-Ask and Illiquidity). Therefore, this study suggests that future studies examine the relationship between IFRS and information asymmetry using different measurements.

\section{NOTES}

1. For detailed information visit: https://www.ifrs.org/use-around-the-world/use-of-ifrs-standards-byjurisdiction/.

2. IFRS identified 7 characteristics to determine the level of IFRS compliance (https://www.ifrs.org/usearound-the-world/use-of-ifrs-standards-by-jurisdiction/). If a country complies with a characteristic, a score of 1 is given and 0 otherwise. The maximum score possible for a country is 7 (full compliance) while the minimum score possible is 0 (non-compliance). 


\section{REFERENCES}

Abad, D. et al. 2017. Does IFRS Mandatory Adoption Affect Information Asymmetry in the Stock Market? Australian Accounting Review: 1-18.

Ahearne, A. G., Griever, W. L. \& Warnock, F. E. 2004. Information costs and home bias : an analysis of US holdings of foreign equities. Journal of International Economics 62: 313-336.

Ahmed, A., Neel, M. \& Wang, D. 2013. Does mandatory adoption of IFRS improve accounting quality?', Contemporary Accounting Research 30(4): 1344-1372.

Akisik, O. 2008. Accounting standards, corporate governance,and foreign direct investments: The experience of emerging market economies. Research in Accounting in Emerging Economies 8: 157-187.

Al-Akra, M., Eddie, I. A. \& Ali, M. J. 2010. The influence of the introduction of accounting disclosure regulation on mandatory disclosure compliance: evidence from Jordan. The British Accounting Review 42(3): 170-186.

Aliabadi, F. J. \& Shahri, A. M. 2016. Transparency in Financial Reporting With or Without IFRS: The Case Of Iran', Muhasebe Bilim, Dünyası Dergisi 18(1): 605-623.

Amihud, Y. 2002. Illiquidity and stock returns: Cross-section and time-series effects. Journal of Financial Markets 5(1): 31-56.

Amihud, Y. et al. 2015. The illiquidity premium: International evidence. Journal of Financial Economics 117(2): $350-368$.

Anderson \& Gatignon. 1986. Modes of entry: a transaction cost analysis and propositions. Journal International Bussiness Studies 17: 1-26.

Armstrong, C. S. et al. 2010. Market Reaction to the Adoption of IFRS in Europe. The Accounting Review 85(1): 3161.

Azubuike, A. A. 2006. Accessibility of Government Information as a Determinant of Inward Foreign Direct Investment in Africa. Paper presented at the World Library and Information Congress: 72nd IFLA General Conference and Council: $1-15$.

Ball, R., Robin, A. \& Wu, J. S. 2003. Incentives versus standards: properties of accounting income in four East Asian countries. Journal of Accounting and Economics 36(1): 235-270.

Bellalah, M., Bradford, M. \& Zhang, D. 2016. A general theory of corporate international investment under incomplete information, short sales and taxes. Economic Modelling 58: 615-626.

Blankespoor, E. A. 2012. The Impact of Investor Information Processing Costs on Firm Disclosure Choice: Evidence from the XBRL Mandate. A PhD Thesis. The University of Michigan.

Callahaa, C. M., Lee, C. M. C. \& Yahn, T. L. 1997. Accounting Information and Bid-Ask Spread. Accounting Horizons 11(4): 50-60.

Chen, C. J. P., Ding, Y. \& Xu, B. 2014. Convergence of accounting standards and foreign direct investment', International Journal of Accounting 49(1): 53-86.

Chipalkatti, N., Le, Q. V. \& Rishi, M. 2007. Portfolio flows to emerging capital markets: Do corporate transparency and public governance matter? Business and Society Review 112(2): 227-249.

Cho, K. et al. 2015. The Effect of International Financial Reporting Standards Adoption on the Relation Between Earnings Quality and Information Asymmetry in Korea. Emerging Markets Finance and Trade 51(sup3): 95117.

Choi, C., Rhee, D. E. \& Oh, Y. 2014. Information and capital flows revisited: The Internet as a determinant of transactions in financial assets', Economic Modelling 40: 191-198.

Coles, J. L., Lemmon, M. L. \& Felix Meschke, J. 2012. Structural models and endogeneity in corporate finance: The link between managerial ownership and corporate performance. Journal of Financial Economics 103(1): 149168.

Core. 2001. A review of the empirical disclosure literature: discussion. Journal of Accounting and Economics 31: 441-456.

Cormier, D. 2014. The Incidence of Corporate Governance and IFRS on Information Asymmetry and the Value Relevance of Earnings : Some Canadian Evidence. Chaire d'Information Financiere et Organisationnelle 3: $1-24$.

Daske, H. et al. 2013. Adopting a Label: Heterogeneity in the Economic Consequences around IAS/IFRS Adoptions. Journal of Accounting Research 51(3): 495-547.

Defond, M. L. \& Jiambalvo, J. 1994. Debt covenant violation and manipulation of accruals. Journal of Accounting and Economics 17: 145-176.

Dhaliwal, D. et al. 2011. Voluntary non-financial disclosure and the cost of equity capital: the case of corporate social responsibility reporting. The Accounting Review 89(1): 59-100. 
Easley, D. et al. 1996. Liquidity, Information, and Infrequently Traded Stocks. Information, and Infrequently Traded Stocks 51(4): 1405-1436.

Eisenhardt, K. M. 1989. Agency Theory: An Assessment and Review. The Academy of Management Review 14(1): 57-74.

Glosten, L. R. \& Milgron, P. R. 1985. Bid,Ask and Transaction Prices in a Specialist Market with Heterogeneously Informed Traders. Journal of Financial Economics 14(1): 71-100.

Gordon, L. A., Loeb, M. P. \& Zhu, W. 2012. The impact of IFRS adoption on foreign direct investment. Journal of Accounting and Public Policy. 31(4): 374-398.

Gujarati, D. 2003. Basic Econometrics. 4th Edition. McGraw-Hili Companies. The USA.

Gujarati, D. N. \& Porter, D. C. 2009. Basic Econometrics. Fifth Edition. Fifth. Mc Graw Hill.

Hayes, A. F. 2013. Introduction to Mediation, Moderation, and Condition Process Analysis.

He, C. 2002. Information costs, agglomeration economies and the location of foreign direct investment in China. Regional Studies 36(9): 1029-1036.

Healy, P. M. \& Palepu, K. G. 2001. Information asymmetry, corporate disclosure, and the capital markets: A review of the empirical disclosure literature. Journal of Accounting and Economics 31(1-3): 405-440.

Hur, S. K. \& Chung, C. Y. 2018. A novel measure of liquidity premium: application to the Korean stock market. Applied Economics Letters 25(3): 211-215.

Jeanjean, T. \& Stolowy, H. 2008. Do accounting standards matter? An exploratory analysis of earnings management before and after IFRS adoption. Journal of Accounting and Public Policy 27(6).

Judge, W., Li, S. \& Pinsker, R. 2010. National adoption of international accounting standards: An institutional perspective', Corporate Governance: An International Review 18(3): 161-174.

Kao, H.-S. \& Wei, T.-H. 2014. The effect of IFRS, information asymmetry and corporate governance on the quality of accounting information. Asian Economic and Financial Review 4(2): 226-256.

Kyle, A. 1985. Continuous auctions and insider trading. Econometrica 53(6): 1315-1335.

Leuz, C. \& Verrecchia, R. E. 2000. The economic consequences of increased disclosure. Journal of Accounting Research 38(1): 91-124.

Liu, C., Luo, X. (Robert) \& Wang, F. L. 2017. An empirical investigation on the impact of XBRL adoption on information asymmetry: Evidence from Europe. Decision Support Systems. 93: 42-50.

Lourenço, I. M. E. C. \& Branco, M. E. M. D. A. D. 2015. Main Consequences of IFRS Adoption: Analysis of Existing Literature and Suggestions for Further Research. Revista Contabilidade \& Finanças 26(68): 126-139.

Michael C. Jensen \& William H. Meckling .1976. Theory of the Firm: Managerial Behavior, Agency Costs and Ownership Structure. Journal of Financial Economics 3(3): 305-360.

MILLER. 1992. A framework for integrated risk management in international business', Journal International Bussiness Studies 23: 311-331.

Mulherin, J. H., Netter, J. M. \& Poulsen, A. B. 2018. Observations on research and publishing from nineteen years as editors of the Journal of Corporate Finance. Journal of Corporate Finance 49: 120-124.

Nagar, V., Schoenfeld, J. \& Wellman, L. 2019. The Effect of Economic Policy Uncertainty on Investor Information Asymmetry and Management Disclosures. Journal of Accounting and Economics 67(1): 36-57.

Naranjo, P., Saavedra, D. \& Verdi, R. S. 2013. Financial Reporting Regulation, Information Asymmetry and Financing Decisions around the World, Working Paper, School of Management, Rice University

Neel, M. 2017. Accounting Comparability and Economic Outcomes of Mandatory IFRS Adoption. Contemporary Accounting Research 34(1): 658-690.

Nejad, M. Y. et al. 2018. International Financial Reporting Standards Foreign Direct Investment in Asean Countries', Gadjah Mada International Journal of Business 20(3): 303-329.

Owusu, Suppiah, \& Hook, S. 2017. IFRS Adoption, Institutional Quality and Foreign Direct Investment Inflows : A Dynamic Panel Analysis. Asian Journal of Business and Accounting 10(2): 43-76.

Persakisa, A. \& Iatridis, G. E. 2017. The joint effect of investor protection, IFRS and earnings quality on cost of capital: An international study. Journal of International Financial Markets, Institutions and Money 5(1): 1930 .

Preiato, Brown \&Tarca. 2009. Mandatory Adoption of IFRS and Analysts' Forecasts: How Much Does Enforcement Matter? Australian School of Business Research Paper 1: 1-58.

Ramamurti, R. 2012. What is really different about emerging market multinationals? Global Strategy Journal 2(1): $41-47$.

Ramanna, K. \& Sletten, E. 2009. Why do countries adopt International Financial Reporting Standards? Working Paper No. 09-102 Accounting and Management Unit, Harvard Business School.

Rehman, I. U. \& Shahzad, F. 2014. The economic consequences of mandatory ifrs reporting: Emerging market 
perspective. Engineering Economics 25(4): 401-409.

Roberts, M. R. \& Whited, T. M. 2013. Endogeneity in Empirical Corporate Finance. Handbook of the Economics of Finance 2(PA): 493-572.

Roberts, Michael \& WhitedToni. 2012. Endogeneity in Empirical Corporate Finance. In Handbook of the Economics of Finance, edited by George M. Constantinides, Milton Harris, and Rene M. Stulz 2.

Samaha, K. \& Khlif, H. 2016. Adoption of and compliance with IFRS in developing countries. Journal of Accounting in Emerging Economies 6(1): 33-49.

Sekaran, U. \& Bougie, R. 2016. Research Methods For Business: A Skill Building Approach. 7th Edition. Wiley.

Sellami, M. 2016. The interaction between real and accrual-based earnings management: analysis based on the mandatory IFRS adoption. International Journal of Accounting and Economics Studies 4(1): 24-31.

Silva Junior, J. C. A. Da, Caldeira, J. F. \& Silva Torrent, H. Da. 2017. Effects of IFRS on Accounting Information Quality: Evidence for Brazil. International Journal of Economics and Finance 9(5): 44-57.

Tabachnick, B. G. \& Fidell, L. S. 2007. Using Multivariate Statistics.

Timm, A. A. et al. 2016. International Financial Reporting Standards and Earnings Management in Latin America. Revista de Administração Contemporânea 20(3): 1-21.

Tsamenyi, M., Adu \& Onumah. 2007. Disclosure and corporate governance in developing countries: Evidence from Ghana. Managerial Auditing Journal 22(3): 319-334.

Turki, H., Wali, S. \& Boujelbene, Y. 2016. The effect of IFRS mandatory adoption on the information asymmetry. Cogent Business \& Management 3(1): 1-19.

Turki, H., Wali, S. \& Boujelbene, Y. 2017. IFRS Mandatory Adoption Effect on the Information Asymmetry: Immediate or Delayed? Australasian Accounting, Business and Finance Journal 11(1): 55-77.

Ulgado. 1997. Location decision-making characteristics of foreign direct investment in the United States. International Business Review 16: 93-271.

Ullah, S., Akhtar, P. \& Zaefarian, G. 2018. Dealing with endogeneity bias: The generalized method of moments (GMM) for panel data. Industrial Marketing Management 71(May): 69-78.

Utama, S., Farahmita, A. \& Anggraita, V. 2016. Economic Consequences of IFRS Adoption in Indonesia 6(1): 7985.

Verona, F. 2014. Investment dynamics with information costs. Journal of Money, Credit and Banking 46(8): 16271656.

Verrecchia, R. 2001. Essays on disclosure. Journal of Accounting and Economics 32(3): 97-180.

Vinh Vo, X. 2018. Determinants of Capital Flows to Emerging Economies - Evidence from Vietnam. Finance Research Letters 27(1): 23-27.

Welker, M. 1995. Disclosure Policy, Information Asymmetry, and Liquidity in Equity Markets. Contemporary Accounting Research 11(2): 801-827.

Yaacob, M. H. et al. 2017. New Dimension of Asymmetric Information in Capital Inflow Composition on ASEAN + 3: A Stock Market Microstructure Approach. International Journal of Economic Research 14(16): 353-360.

Yousefinejad, M., Ahmad, A. \& Rahim, A. 2018. The Mediating Effect of Information Asymmetry on IFRS and Foreign Direct Investment. International Journal of Economics and Management 12(September): 641-656.

Zhai, J. \& Wang, Y. 2016. Accounting information quality, governance efficiency and capital investment choice. China Journal of Accounting Research 9(4):251-266.

Maryam Yousefi Nejad*

Department of Accounting and Finance

Faculty of Business Management \& Professional Studies (FBMP)

Management and Science University

University Drive, Off Persiaran Olahraga

40100 Shah Alam, Selangor

Malaysia

E-mail: maryam_yousefi@msu.edu.my

Azlina Ahmad

Faculty of Economics and Management

Universiti Kebangsaan Malaysia

43600 UKM Bangi Selangor

MALAYSIA

E-mail: azlina@ukm.edu.my 


\section{Ruzita Abdul Rahim}

Faculty of Economics and Management

Universiti Kebangsaan Malaysia

43600 UKM Bangi Selangor

MALAYSIA

E-mail: ruzitaar@ukm.edu.my

\section{Fairuz Md Salleh}

Faculty of Economics and Management Universiti Kebangsaan Malaysia

43600 UKM Bangi Selangor

MALAYSIA

E-mail: fairuz@ukm.edu.my

*Corresponding author 